\title{
PERANAN KREDIT KETAHANAN PANGAN DAN ENERGI DALAM PENINGKATAN PRODUKSI DAN KEUNTUNGAN USAHATANI PADI DI KABUPATEN KAMPAR, RIAU PROVINSI
}

\author{
Roles of Food Security and Energy Credit in Increasing Rice Production and \\ Profits in Kampar Regency, Riau Province
}

\author{
Ilma Satriana Dewi, Dwi Rachmina, Netti Tinaprilla \\ Departemen Agribisnis, Pascasarjana Institut Pertanian Bogor (IPB) \\ Jl. Kamper Wing 4 Level 5 Dramaga, Bogor. 16680 \\ [Diterima Mei 2015, Disetujui Juni 2015]
}

\begin{abstract}
The majority of farmers with small scale enterprises are still facing a capital shortage primarily rice farming. Capital constraints caused farmers must perform farm activities with a limited input. Limited input causing the output and the revenue generated is not optimal. Food security and energy credits are one of the credit which intends to help especially rice farmers. By the low interest rate, this credit is expected to help farmers for improving the use of inputs and increasing the output and revenue. The aims of study are to evaluate the use of credit on production activities and to analyze the increase in rice farming profits before and after the credits. Research methods used in this research were descriptive analysis, multiple regression analysis, and different test ( $t$-test). The results showed that the rice farmers used KKPE for $53 \%$ for rice farming which included the purchase of equipment and farm machinery, production inputs and labor wage. An increase in rice farming profits, but not affected by the credit, and from the $t$-test result that there was no difference profits before and after credit.
\end{abstract}

Keywords: Credits, Rice production, Rice farming profits

\begin{abstract}
ABSTRAK
Mayoritas petani dengan skala usaha kecil masih mengalami kekurangan modal salah satunya pada usahatani padi. Keterbatasan modal menyebabkan petani melakukan kegiatan usahatani dengan input yang terbatas. Input yang terbatas menyebabkan output dan penerimaan yang dihasilkan tidak optimal. Kredit Ketahanan Pangan dan Energi (KKPE) merupakan salah satu kredit yang ditujukan untuk membantu petani padi khususnya. Dengan bunga pengembalian yang rendah diharapkan kredit ini bisa membantu petani meningkatkan penggunaan input dan meningkatkan output serta penerimaan. Tulisan ini bertujuan untuk mengevaluasi penggunaan kredit pada kegiatan produksi dan menganalisis peningkatan keuntungan usahatani padi sebelum dan setelah kredit. Metode penelitian menggunakan alat analisis berupa analisis deskriptif dan analisis regresi berganda serta uji beda (ujit). Hasil penelitian menunjukkan bahwa petani padi menggunakan KKPE sekitar 53 persen untuk usahatani padi meliputi pembelian alat dan mesin pertanian, sarana produksi dan upah tenaga kerja. Terjadi peningkatan keuntungan usahatani padi, namun bukan dipengaruhi oleh kredit, dan dari uji $t$ diperoleh hasil bahwa tidak terdapat perbedaan keuntungan sebelum dan setelah kredit.
\end{abstract}

Kata Kunci: Kredit, Produksi padi, Keuntungan usahatani padi

\section{PENDAHULUAN}

Permodalan merupakan salah satu permasalahan utama yang hingga saat ini masih dihadapi oleh petani khususnya pada usaha pertanian dalam skala kecil. Sekitar 69,82\% usaha yang dijalankan petani khususnya pada skala usaha kecil, masih menggunakan modal sendiri dengan jumlah yang terbatas dan kecil. Petani sulit untuk melakukan akses modal dari perbankan, sementara di satu sisi usaha mereka mengharuskan perlunya tambahan modal yang besar. Pengalokasian kredit formal di sektor pertanian masih relatif kecil. 
Berdasarkan data dari Bank Indonesia (2013) dari $\mathrm{Rp} 526,4$ triliun kredit untuk UMKM, penyaluran kredit terbesar ke sektor perdagangan mencapai 47,2 persen, sedangkan ke sektor pertanian hanya 7,73 persen atau sebesar Rp 40,70 triliun. Selanjutnya, dari Rp 40,70 triliun untuk sektor pertanian ini, sebanyak 56,29 persen disalurkan ke sektor perkebunan seperti kelapa sawit dan tebu. Sedangkan untuk sektor tanaman pangan hanya 8 persen, hortikultura mencapai 6 persen dan peternakan sebesar 17,94 persen.

Keberadaan kredit benar-benar dibutuhkan oleh petani untuk tujuan produksi, pengeluaran hidup sehari-hari sebelum hasil panen terjual dan untuk pertemuan sosial lainnya. Penguasaan lahan yang tergolong sempit, upah yang mahal dan kesempatan kerja terbatas di luar musim tanam, menyebabkan sebagian besar petani tidak dapat memenuhi biaya hidupnya dari satu musim ke musim lainnya tanpa pinjaman.

Terkait dengan penguasaan lahan padi, mulai tahun 2010 hingga tahun 2013 terjadi penurunan produksi padi di Provinsi Riau. Adapun beberapa hal yang menyebabkan menurunnya produksi padi ini antara lain, berkurangnya luas lahan akibat alih fungsi lahan, penerapan teknologi yang belum optimal terutama pada penggunaan benih dan pupuk. Infrastruktur jaringan irigasi yang tidak memadai. Jika hal ini tidak segera diantisipasi dikhawatirkan bisa menyebabkan hilangnya areal sawah potensial di kawasan Provinsi Riau dan berganti dengan perkebunan kelapa sawit. Misalnya, pada tahun 2012 dengan lahan yang tersedia dapat memproduksi tanaman pangan sebanyak 648.310 ton/tahun, namun pada tahun 2013 produksinya menurun menjadi 577.805 ton/tahun. Jumlah tersebut belum mencukupi kebutuhan tanaman pangan pada tahun 2013 sebanyak 629.600 ton/tahun, sehingga masih terdapat kekurangan tanaman pangan sebesar 51.795 ton/tahun. Jika alih fungsi lahan ini tidak segera dikendalikan maka di Riau akan mengalami defisit tanaman pangan (Badan Pusat Statistik, 2014).

Permasalahan-permasalahan yang dihadapi petani khususnya pada petani padi seperti kurangnya modal, berkurangnya luas areal usahatani dan menurunnya jumlah produksi dapat diupayakan melalui tambahan modal berupa kredit. Kredit bukan sebagai syarat mutlak dalam pengembangan usaha pertanian. Namun kredit dapat menjadi pelancar dalam pengembangan usahanya dan motivasi bagi petani untuk lebih meningkatkan kualitas pertanian mereka salah satunya melalui adopsi teknologi dan budidaya (Mosher, 1965; Mubyarto, 1989). Namun, tidak semua kredit yang diberikan untuk sektor pertanian dimanfaatkan dengan baik oleh petani dan berpengaruh positif terhadap produksi dan pendapatan usaha ataupun terhadap pengembangan usahanya. Jikapun ada yang berhasil meningkatkan produksi, tetapi belum tentu berpengaruh positif terhadap peningkatan pendapatan.

KKPE merupakan salah satu kredit yang paling sering diberikan kepada petani khususnya untuk petani tanaman pangan. Pada tahun 2011, sebanyak Rp 10,91 triliyun (120\%) dari plafon KKPE sebesar Rp 8,5 triliyun berhasil disalurkan oleh Bank Umum maupun Bank Pembangunan Daerah (BPD). Sekitar 73 persen KKPE digunakan untuk budidaya tanaman tebu. Pembiayaan untuk budidaya tanaman pangan seperti padi, jagung dan kedelai hanya mencapai 7 persen. Untuk pengadaan pangan dan atau pembelian gabah hanya mendapat alokasi kredit sebesar 1,4 persen dari total plafon (Direktorat Pembiayaan, 2011).

Pada tahun 2012, realisasi KKPE oleh perbankan di Riau baru mencapai Rp 13,33 milyar, kemudian meningkat sebesar 159,16 persen pada triwulan 1 tahun 2013 atau sebesar Rp 34,54 milyar. Jika dibandingkan dengan triwulan sebelumnya penyaluran KKPE sebesar Rp 30,67 miliar, artinya terjadi peningkatan sebesar 12,62 persen. Peningkatan realisasi kredit KKPE di Riau tercatat lebih tinggi dari penyaluran KUR, dimana pada triwulan I-2013, penyaluran KUR mencapai Rp 3,41 triliun dan naik 10,77 persen dibandingkan triwulan sebelumnya. KKPE juga memiliki bunga kredit yang lebih rendah yaitu sebesar 6 persen dibandingkan KUR dengan kredit maksimum 13 persen. Rendahnya bunga kredit KKPE disebabkan adanya subsidi bunga yang diberikan oleh pemerintah sebesar 8,5 persen. Peningkatan jumlah KKPE dan bunga kredit yang rendah diharapkan dapat membantu petani dalam peningkatan usaha khususnya pada produksi dan keuntungan (Anggoro, 2013). 
Tabel 1. Jumlah Produksi Padi di Provinsi Riau, Tahun 2010-2013

\begin{tabular}{cccccc}
\hline $\begin{array}{c}\text { Tanaman Pangan } \\
\text { (padi) }\end{array}$ & 2010 & 2011 & 2012 & 2013 & $\begin{array}{c}\text { Taju } \\
\text { pertumbuhan } \\
(\% / \text { tahun })\end{array}$ \\
\cline { 2 - 5 } & & & & & \\
\hline Jumlah produksi (ton) & 711.662 & 668.164 & 648.310 & 577.805 & $(4,12)$ \\
Produktivitas (Ku/Ha) & 49,97 & 52,21 & 59,53 & 62,99 & 7,35 \\
\hline Sumber: Badan Pusat Statistik (2013) & & & &
\end{tabular}

Penyaluran KKPE untuk petani di Riau terus meningkat. Jika dibandingkan dengan produksi tanaman padi pada Tabel 1 , menunjukkan kondisi yang berlawanan yaitu semakin menurunnya produksi padi. Tidak sejalannya peningkatan realisasi KKPE dengan produksi padi, kemungkinan disebabkan penyalurannya yang masih rendah untuk tanaman ini.

Selain itu, kredit yang disalurkan pada petani padi tidak selalu digunakan untuk usahatani nya tetapi digunakan untuk usahausaha non pertanian (fungibility of credit). Adanya kondisi demikian maka dirasa perlu dilakukan penelitian dengan tujuan untuk mengevaluasi penggunaan kredit ketahanan pangan dan energi (KKPE) dalam kegiatan produksi dan bagaimana keuntungan usahatani padi dengan adanya KKPE di kabupaten Kampar Riau.

\section{METODE PENELITIAN}

Lokasi penelitian dilakukan di kabupaten Kampar yang dipilih secara purposive dengan pertimbangan lokasi ini merupakan daerah yang berpotensi untuk dikembangkan usahatani padi dengan potensi lahan sebesar $31.348 \mathrm{Ha}$. Selain itu, lokasi ini merupakan salah satu sentra produksi padi di Provinsi Riau dengan jumlah produksi padi mencapai 53.232,36 ton. Penelitian ini telah dilakukan pada bulan Maret sampai April 2015.

Data penelitian terdiri dari data primer dan sekunder. Data primer diperoleh dengan metode survey melalui wawancara kepada petani padi yang menerima kredit (KKPE). Data sekunder diperoleh dari berbagai sumber seperti instansi terkait terdiri dari Dinas Pertanian kabupaten Kampar, dan Badan Pusat Statistik (BPS) Kampar, jurnal, karya ilmiah, artikel, dokumentasi dan data pendukung lainnya.

Responden pada penelitian ini merupakan petani padi penerima kredit (KKPE) dari beberapa sumber bank. Metode pengambilan responden dilakukan secara purposive sampling dengan asumsi petani yang dijadikan responden penelitian merupakan petani yang menerima KKPE minimal pada tahun 2013 dan sudah panen minimal 1 kali setelah menerima kredit tersebut. Berdasarkan data yang diperoleh jumlah responden yang sesuai dengan asumsi di atas berjumlah 100 responden.

Metode analisis data pada penelitian ini terdiri dari analisis data secara deskriptif kualitatif maupun kuantitatif. Analisis deskriptif kualitatif digunakan untuk mengevaluasi penggunaan kredit oleh petani pada kegiatan produksi, serta melihat gambaran karakteristik usahatani padi di daerah penelitian. Analisis kuantitatif dilakukan untuk mengetahui pengaruh kredit terhadap peningkatan keuntungan usahatani, serta menghitung dan membandingkan keuntungan usahatani sebelum memperoleh kredit dengan keuntungan usahatani setelah memperoleh kredit. Sebelum dilakukan analisis untuk melihat pengaruh kredit terhadap usahatani dilakukan analisis keuntungan usahatani. Analisis ini didasarkan pada penerimaan dan biaya yang dikeluarkan dalam kegiatan usahatani. Oleh karena itu, keuntungan dari usahatani padi sebelum memperoleh kredit diperkirakan dengan menggunakan persamaan berikut:

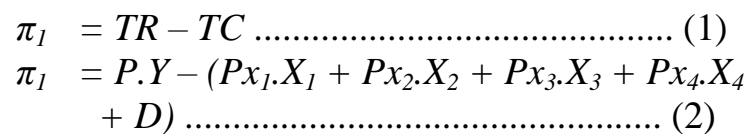

Dimana:

$\pi_{1}=$ Keuntungan usahatani sebelum memperoleh pinjaman $(\mathrm{Rp})$

$\mathrm{P}=$ Harga output $(\mathrm{Rp} / \mathrm{kg})$

$\mathrm{Y}=$ Jumlah output $(\mathrm{kg})$

$\mathrm{Px}_{1}=$ Harga benih padi $(\mathrm{Rp})$

$\mathrm{X}_{1}=$ Jumlah bibit

$\mathrm{Px}_{2}=$ Harga pupuk $(\mathrm{Rp} / \mathrm{kg})$

$\mathrm{X}_{2}=$ Jumlah pupuk $(\mathrm{kg})$

$\mathrm{Px}_{3}=$ Harga pestisida $(\mathrm{Rp} / \mathrm{botol})$

$\mathrm{X}_{3}=$ Pestisida (botol)

$\mathrm{Px}_{4}=$ Upah tenaga kerja $(\mathrm{Rp} / \mathrm{HOK})$

$\mathrm{X}_{4}=$ Jumlah tenaga kerja (HOK) 
$\mathrm{D}=$ Depresiasi (penyusutan alat dan mesin pertanian) (Rp)

Sementara, besarnya keuntungan petani setelah memperoleh kredit diperkirakan dengan menggunakan persamaan berikut:

$\pi_{2}=T R-T C-I$

Dimana:

$\pi_{2}=$ Keuntungan usahatani setelah memperoleh pinjaman $(\mathrm{Rp})$

$\mathrm{I}=$ Tingkat bunga pinjaman yang dibayar (Rp/bulan).

Selanjutnya, untuk menguji adanya perbedaan atau peningkatan keuntungan setelah memperoleh kredit dibandingkan sebelum memperoleh kredit, maka selanjutnya perlu dilakukan uji secara statistik yaitu melalui uji beda (uji t). Uji beda dilakukan dengan menggunakan teknik dependen sample test dimana teknik ini menguji perbedaan pada 1 kelompok sampel petani/responden penelitian dengan 2 treatment yang berbeda yaitu pendapatan sebelum memperoleh kredit dan pendapatan setelah memperoleh kredit. Dalam menghitung uji beda ini perlu adanya hipotesis sebagai berikut:

H0: Tidak ada perbedaan keuntungan usahatani setelah memperoleh kredit

H1: Ada perbedaan keuntungan usahatani setelah memperoleh kredit

Untuk menganalisis uji beda ini digunakan rumus sebagai berikut:

$t=\frac{\bar{D}}{\left(\frac{S D}{\sqrt{N}}\right)}$

Dimana:

$\mathrm{t}=$ Nilai $\mathrm{t}$ hitung

$\bar{D}=$ Rata-rata selisih keuntungan 1 dan 2

$\mathrm{SD}=$ Standar deviasi

$\mathrm{N}=$ Jumlah responden

Dengan rumus standar deviasi sebagai berikut:

$S D=\sqrt{\frac{\sum D^{2}-\sum \frac{D^{2}}{n}}{n-1}}$

Untuk mengintepretasikan nilai $\mathrm{t}$ hitung perlu ditentukan nilai $\alpha$ yang mana dalam penelitian ini ditetapkan nilai $\alpha$ sebesar $5 \%$. Selanjutnya nilai t-hitung dibandingkan dengan t-tabel. Apabila t-hitung > t-tabel artinya ada perbedaan pendapatan secara signifikan setelah memperoleh kredit (tolak H0), dan apabila thitung $<\mathrm{t}$-tabel artinya tidak ada perbedaan pendapatan secara siginifikan setelah memperoleh kredit (terima H0).

Analisis yang digunakan untuk menduga adanya pengaruh kredit terhadap keuntungan adalah dengan analisis regresi berganda yang terdiri dari beberapa variabel independen yang diduga berpengaruh terhadap keuntungan usahatani. Persamaan regresi nya adalah sebagai berikut:

$\pi=\alpha+\beta 1 X 1+\beta 2 X 2+\beta 3 X 3+\beta 4 X 4+\beta 5 X 5+\beta 6 X 6+\beta 7 X 7+\varepsilon \ldots$

Keterangan:

$\pi=$ Keuntungan usahatani $(\mathrm{Rp} / \mathrm{musim}$ tanam)

$\mathrm{X} 1=$ Harga output $(\mathrm{Rp} / \mathrm{kg})$

$\mathrm{X} 2=$ Luas lahan (ha)

$\mathrm{X} 3=$ Jumlah kredit (Rp)

$\mathrm{X} 4 \quad=$ Harga benih $(\mathrm{Rp} / \mathrm{kg})$

$\mathrm{X} 5 \quad=$ Harga pupuk $(\mathrm{Rp} / \mathrm{kg})$

$\mathrm{X} 6=$ Harga pestisida $(\mathrm{Rp} / \mathrm{botol})$

$\mathrm{X} 7 \quad=$ Upah tenaga kerja $(\mathrm{Rp} / \mathrm{HOK})$

$\alpha \quad=$ Konstanta

$\beta_{1,2,3,4,5,6}=$ Koefisien atau parameter yang hendak dihitung

$\varepsilon \quad=$ Error

Hipotesis untuk persamaan di atas adalah:

H0: Tidak terdapat pengaruh antara variabel independen (X1, X2, X3, X4, X5,X6) terhadap keuntungan usahatani

H1: Terdapat pengaruh antara variabel independen (X1, X2, X3, X4, X5,X6) terhadap keuntungan usahatani.

Penentuan variabel-variabel independen pada persamaan regresi di atas didasarkan pada konsep keuntungan maksimum, dimana dari konsep tersebut dikatakan bahwa keuntungan maksimum dapat dicapai pada nilai produksi marjinal sama dengan harga input (Lau, 1978). Secara matematis, dapat ditulis sebagai berikut:

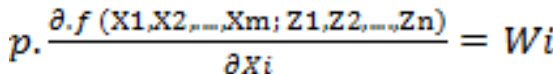

Jika persamaan di atas dinormalkan dengan harga output, didapat persamaan sebagai berikut: 


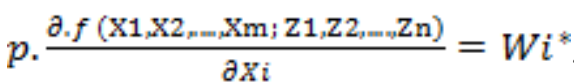

Dimana: $\mathrm{Wi}^{*}=\mathrm{Wi} / \mathrm{p}=$ harga input ke-i yang dinormalkan dengan harga output.

Jika persamaan 8 dinormalkan dengan harga output, diperoleh persamaan sebagai berikut:

$\pi^{*}=\pi / p=p . f\left(X_{1}, X_{2}, \ldots \ldots, X_{m} ; Z_{1}, Z_{2}, \ldots \ldots, Z_{n}\right)-$ $\sum_{i=1}^{m} W i^{*} \cdot X i^{*}$

Dimana: $\pi^{*}$ dikenal sebagai fungsi keuntungan UOP atau Unit Output Price Profit Function.

Jumlah optimal dari input peubah Xi yang memberi keuntungan maksimum jangka pendek dapat diturunkan dari persamaan 9, yaitu:

$X i^{*}=f\left(W_{1}, W_{2}, \ldots, W_{m} ; Z_{l}, Z_{2}, \ldots, Z_{n}\right)$

Subtitusi persamaan 10 ke dalam persamaan 11 maka didapatkan persamaan sebagai berikut:

$\pi=p . f\left(X_{1}, X_{2}, \ldots \ldots, X_{m} ; Z_{1}, Z_{2}, \ldots \ldots ., Z_{n}\right)-$ $\sum_{i=1}^{m} W i^{*} \cdot X i^{*}$

Karena $\mathrm{Xj}^{*}$ sebagai fungsi dari $\mathrm{Wi}^{*}$ dan $\mathrm{Jz}$, maka persamaan 11 dapat ditulis sebagai berikut:

$\pi=p . G^{*}\left(W_{1}^{*}, W_{2}{ }^{*}, . ., W_{m}{ }^{*} ; Z_{1}, Z_{2}, . ., Z_{n}\right) \ldots$

Persamaan 12 merupakan fungsi keuntungan yang memberikan nilai maksimum dari keuntungan jangka pendek untuk masingmasing harga output, harga input tidak tetap Wi dan tingkat input tetap $\mathrm{Zj}$. Jika persamaan tersebut dinormalkan dengan harga output, maka didapat.

$\pi^{*}=\pi / p=G^{*}\left(W_{1}{ }^{*}, W_{2}{ }^{*}, . ., W_{m}{ }^{*} ; Z_{1}, Z_{2}, . ., Z_{n}\right) .$.

Persamaan 13 merupakan fungsi keuntungan UOP sebagai fungsi dari harga input tidak tetap yang dinormalkan dengan harga output dan sejumlah input tetap.

\section{HASIL DAN PEMBAHASAN}

Kredit Ketahanan Pangan dan Energi (KKPE) adalah kredit ivestasi dan atau modal kerja yang diberikan dalam rangka mendukung pelaksanaan program peningkatan ketahanan pangan dan energi nasional. Sektor usaha yang dibiayai dalam kredit ini di antaranya adalah sektor tanaman pangan seperti gabah, jagung, kedelai dan padi, sektor perikanan dan sektor peternakan.
Tujuan adanya kredit ini untuk pengembangan pada masing-masing sektor yang memperoleh kredit ketahanan pangan dan energi. Usahatani padi di kabupaten Kampar juga mendapat bantuan kredit ini. Namun, pada usahatani padi penyaluran kredit ini masih sangat minim. Sehingga, masih banyak petanipetani padi di daerah ini yang belum merasakan manfaat dari kredit tersebut. Untuk selanjutnya, akan dibahas bagaimana petani mengajukan KKPE dan seberapa besar kredit yang dimanfaatkan untuk kegiatan usahataninya. Kredit Ketahanan Pangan dan Energi (KKPE) untuk usahatani padi di kabupaten Kampar belum banyak petani padi yang mengetahuinya. Sehingga untuk petani penerima kredit ini juga masih sangat sedikit.

Berdasarkan hasil penelitian, sekitar 85 persen petani padi responden yang menerima kredit mengatakan bahwa petani mengajukan kredit karena adanya penawaran dari pihak bank. Mayoritas petani tidak mengetahui adanya program kredit ini. Sisanya, 15 persen petani padi mengetahui informasi mengenai kredit ini dari petani non padi yang juga menerima KKPE. Alasan petani mengajukan kredit ini selain adanya tawaran kredit dari pihak perbankan, petani padi memang masih mengalami keku-rangan modal untuk usahatani.

Pemanfataan kredit pada usahatani digunakan untuk membeli kebutuhan input. Petani yang awalnya tidak memiliki traktor atau hanya menyewa, setelah menerima kredit digunakan untuk membeli traktor. Selain itu, petani juga menggunakan kredit untuk menambah peralatan usahatani lainnya seperti cangkul, sabit, hand sprayer dan mesin perontok padi. Dengan menggunakan modal dari kredit, petani dapat menggunakan pupuk non-subsidi yang kualitas nya lebih baik dibandingkan pupuk bersubsidi meskipun harga jualnya lebih murah. Kredit juga dimanfaatkan untuk menambah jumlah kebutuhan benih.

Selain untuk kegiatan usahatani, kredit juga digunakan petani untuk kebutuhan hidup mereka sehari-hari pada saat musim tanam atau sebelum panen. Sisa kredit yang ada digunakan oleh sebagian petani responden untuk kebutuhan rumah tangga lainnya. Tabel 2 menunjukkan proporsi pemanfaatan atau penggunaan kredit secara umum dari petani responden. Berdasarkan Tabel 2, dapat disimpulkan sekitar 
52,58 persen kredit digunakan untuk kepentingan usahatani, sebesar 24,08 persen untuk tambahan kebutuhan sehari-hari selama musim tanam dan sisanya 23,33 persen untuk kebutuhan atau usaha lain yang bukan di sektor pertanian.

Hasil penelitian menyimpulkan bahwa kredit yang diterima petani lebih dari 50 persen lebih banyak digunakan untuk kebutuhan usahatani dibandingkan untuk kebutuhan non usahatani. Petani juga menggunakan kredit untuk kebutuhan sehari-hari dalam persentase yang cukup besar. Hal ini disebabkan karena proses produksi yang dilakukan petani sebagian besar hanya satu kali musim tanam, sehingga hasil yang diterima dari usahatani tersebut tidak dapat mencukupi kebutuhan sehari-hari. Untuk mencukupinya, petani akhirnya menggunakan sebagian kredit yang mereka terima.

Terjadi peningkatan penggunaan input atau sarana produksi sebelum dan setelah menerima kredit. Adapun input-input yang mengalami peningkatan terdiri dari benih, dan pupuk seperti pupuk urea, pupuk $\mathrm{KCl}$, pupuk organik, dan pupuk Abu. Penggunaan benih meningkat sebesar 42,31 persen dibandingkan sebelum petani menerima kredit. Selanjutnya, penggunaan pupuk urea yang meningkat sebesar 17,83 persen, pupuk $\mathrm{KCl}$ meningkat sebesar 18,78 persen, pupuk organik meningkat sebesar 7,59 persen, dan pupuk abu yang meningkat sebesar 1,04 persen.

Input produksi lainnya yang juga mengalami peningkatan adalah alat dan mesin pertanian juga terjadi peningkatan jumlah dari sebelumnya dengan adanya kredit. Hand traktor sebagai alat untuk mengolah sawah mengalami peningkatan sebesar 49 persen, kemudian sabit meningkat sebesar 67,30 persen, cangkul meningkat sebesar 47,20 persen, hand sprayer meningkat sebesar 25,92 persen, dan mesin perontok padi meningkat sebesar 80,28 persen.
Meningkatnya input-input dan alat serta mesin pertanian berpengaruh positif terhadap peningkatan produksi. Adapun rata-rata produksi padi sebelum menerima kredit berjumlah 1.951,60 $\mathrm{kg} / \mathrm{ha} / \mathrm{MT}$. Sedangkan, rata-rata produksi padi setelah kredit berjumlah $2.370,50 \mathrm{~kg} / \mathrm{ha} / \mathrm{MT}$.

Keuntungan usahatani padi dari hasil analisis usahatani relatif mengalami peningkatan setelah menerima kredit. Peningkatan ini disebabkan adanya peningkatan produksi padi dan harga output yang juga meningkat. Adapun keuntungan usahatani sebelum menerima kredit adalah sebesar Rp. 7.186.437/MT dan setelah kredit meningkat sebesar 11,42 persen atau berjumlah sekitar Rp. 8.113.134/MT. Selain disebabkan karena produksi dan harga yang meningkat, terdapat beberapa faktor yang berpengaruh signifikan terhadap keuntungan yang diperoleh berdasarkan analisis regresi berganda terhadap keuntungan usahatani. Faktor-faktor yang berpengaruh signifikan terhadap keuntungan usahatani padi, antara lain: harga output, luas lahan, harga benih, harga pupuk urea, harga pupuk $\mathrm{KCl}$, dan upah tenaga kerja.

Sementara untuk faktor jumlah kredit, hasil analisis memperoleh bahwa jumlah kredit tidak berpengaruh signifikan terhadap peningkatan keuntungan. Meskipun secara perhitungan terjadi perbedaan keuntungan sebelum dan setelah kredit, namun secara statistik belum tentu terjadi perbedaan keuntungan pada usahatani baik sebelum ataupun setelah kredit. Sehingga, perlu dilakukan uji beda (uji-t). Dari uji yang dilakukan menghasilkan nilai t statistic sebesar $-8,771$ yang nilainya lebih kecil dari $\mathrm{t}$ tabel $5 \%=1,66$ yang artinya menerima hipotesis nol (terima $H O$ ). Maka, dari hasil tersebut dapat disimpulkan bahwa tidak terdapat perbedaan keuntungan usahatani setelah menerima kredit.

Tabel 2. Proporsi Penggunaan KKPE oleh Petani Padi di Kabupaten Kampar, Tahun 2015

\begin{tabular}{lc}
\hline Bentuk pemanfaatan kredit & Proporsi (\%) \\
\hline Pembelian mesin dan alat pertanian & 37,78 \\
Pembelian sarana produksi (pupuk organik dan kimiawi) dan bahan bakar & 5,69 \\
Benih & 0,65 \\
Upah tenaga kerja & 8,45 \\
Kebutuhan sehari-hari (rumah tangga) & 24,08 \\
Kebutuhan lainnya (non pertanian) & 23,33 \\
\hline Jumlah & 100,00 \\
\hline
\end{tabular}




\section{KESIMPULAN}

1. Pada umumnya petani padi di daerah penelitian masih mengalami kekurangan modal untuk mengembangkan usahatani nya. Sehingga petani membutuhkan tambahan modal. Namun, petani pada umumnya juga tidak mengetahui informasi sumber untuk memperoleh tambahan modal. Kredit Ketahanan Pangan dan Energi (KKPE) yang diterima petani padi sebagian besar diajukan petani karena adanya penawaran dari pihak bank, sehingga jumlah petani yang mengajukan dan menerima kredit ini sangat terbatas.

2. Pemanfaatan kredit pada usahatani rata-rata sudah mencapai lebih dari 50 persen. Petani juga banyak menggunakan kredit untuk kebutuhan sehari-hari dan untuk usaha lainnya. Penggunaan kredit yang cukup besar untuk kebutuhan sehari-hari dikarenakan penerimaan dari usahatani padi tidak dapat mencukupi kebutuhan mereka selama saat musim tanam berikutnya. Dengan adanya kredit membuat petani dapat memanfaatkan penggunaan input secara optimal dan menggunakan input dengan kualitas yang lebih baik. Sehingga, dari perbaikan maupun kualitas input tersebut berdampak pada terjadi nya peningkatan produksi.

3. Peningkatan produksi setelah petani menerima kredit dan diikuti dengan adanya peningkatan harga menyebabkan meningkatnya keuntungan usahatani, tetapi jumlah kredit tidak berpengaruh positif terhadap peningkatan keuntungan tersebut.

\section{DAFTAR PUSTAKA}

Anggoro, R. 2013. Realisasi Kredit KKPE Riau. Online pada: http://foto.antarariau.com. Diakses pada Desember 2014.

Badan Pusat Statistik. 2013. Riau Dalam Angka, Pekanbaru.

Badan Pusat Statistik. 2014. Riau Dalam Angka, Pekanbaru.

Bank Indonesia. 2013. Statistik Bank Indonesia: Penyaluran Kredit Perbankan. Bank Indonesia Riau, Pekanbaru.

Direktorat Pembiayaan Pertanian. 2001. Pedoman Teknis Skim Kredit Ketahanan Pangan dan Energi (KKPE). Skim Kredit Bersubsidi untuk Petania/Peternak. Di- rektorat Jenderal Prasarana dan Sarana Pertanian. Kementerian Pertanian, Jakarta.

Mosher, A. T. 1965. Menggerakan dan Membangun Pertanian. Yasaguna, Jakarta.

Mubyarto. 1989. Pengantar Ekonomi Pertanian. LP3ES, Jakarta.

Lau, L. J. 1978. Applications of Profit Functions in Production Economics: A Dual Approach to Theory and Applications, Amsterdam. 
